\title{
Drivers of Attitudinal and Behavioural Loyalty in B-2-B Markets
}

\author{
Vytautas Dikcius $^{1}$, Sigita Kirse ${ }^{2}$, Ramunas Casas $^{3}$, Ana Koncanina ${ }^{4}$ \\ ${ }^{1,2,3}$ Vilnius University \\ Universiteto str. 3, LT-01513, Vilnius, Lithuania \\ E-mail.vytautas.dikcius@evaf.vu.lt,kirse.sigita@gmail.com,ramunas.casas@evaf.vu.lt
}

${ }^{4} U A B$ Euroglass

Ukmerges st. 427, LT-12107, Vilnius, Lithuania

E-mail.anna.koncanina@carglass.lt

cross $^{\text {ref }}$ http://dx.doi.org/10.5755/j01.ee.30.1.20182

\begin{abstract}
There is no doubt that loyalty is one of the most frequently explored topics. However, this might not be the case with the loyalty in the business-to-business market. That is also true about the research of the loyalty-forming constructs: it is unclear whether the constructs, which influence loyalty in B-2-C market-perceived quality, switching costs, commitment, trust, and satisfaction - have an impact on loyalty in the B-2-B market, too. The paper aims to evaluate an impact of the main drivers on the two types of loyalty - behavioural and attitudinal - in the case of B-2-B market. The survey of B-2-B service companies, performed in a small transition economy, has proved the significance of the selected factors for the measurement of loyalty. The high level of determination coefficient showed that the models included the most important factors. However, some factors had a direct impact, while other factors influenced loyalty indirectly. Switching costs and attitudinal loyalty had a direct impact on behavioural loyalty. At the same time, satisfaction had a direct impact on attitudinal loyalty, making an influence of the behavioural loyalty as well. Meanwhile, the impact of trust, perceived quality and commitment on attitudinal loyalty was strongly mediated by the perception of satisfaction.
\end{abstract}

Keywords: Switching Costs; Commitment; Trust, Satisfaction; Behavioural Loyalty; Attitudinal Loyalty; B-2-B Market; Mediation.

\section{Introduction}

Customer loyalty is one of the main marketing tasks for every company (Evanschitzky et al., 2006). Companies spend billions on the development of customers' loyalty, while scientists write numerous articles on this topic. For a long time, it was mainly related to B-2-C markets, but it seems that loyalty is essential for the business-to-business markets as well (Skarmeas et al., 2016; Vaitone-Vilkaite \& Papsiene, 2016). The previous research showed that satisfaction is the key determinant of customer loyalty (Wirtz et al., 2014; Askariazad \& Babakhani, 2015). However, Kumar et al. (2013) concluded that satisfaction was not sufficient to explain loyalty fully, and some additional factors had to be included for getting a complete picture. Importance of trust on customers' loyalty was analysed by Wu et al. (2015) and El-Manstrly (2016). Other authors (Stan, 2015; Ram \& Wu, 2016) have evaluated the impact of perceived switching costs on loyalty. The commitment was included in some studies as well (Lariviere et al., 2014; Wu et al., 2015). Finally, some authors have argued that perceived quality could be crucial for reaching customers' loyalty (Biedenbach et al., 2015; Lai, 2015).

Despite a number of previous studies, related to the understanding of the factors that drive customer loyalty (Caruana \& Ewing, 2010; Ding et al., 2011; Gassmann \& Oliver, 2011), most of these studies were related to behavioural loyalty in the business-to-business context. DeMatos \& Rossi (2008) noticed that unidimensional (behavioural) perception of loyalty is too narrow, and attitudinal loyalty should be taken into account when loyalty is measured. Moreover, various drivers could have a different impact on both types of loyalty (Gecti \& Zengin, 2013, Banyte et al., 2014). Therefore, we conclude that existing theories could not explain which factors influence different types of loyalty. Thus, the scientific problem could be postulated in the following way: which of the predetermined factors (perceived switching costs, commitment, trust, perceived quality and satisfaction) influence attitudinal and behavioural loyalty in B-2-B market?

An analysis of the most recent scientific articles revealed that previous studies were somewhat fragmentary. The integrated approach, used in the research and data analysis, explains the interrelation of the analyzed variables and testifies the novelty of the article. Moreover, the impact of the factors mentioned above was measured in relation to the two types of loyalty. It is worth to notice that just a minority of previous studies, related to drivers of attitudinal and behavioural loyalty, were performed in the business-tobusiness markets. Thus, the research would be valuable for improving theoretical knowledge about drivers of loyalty in B-2-B context. Some authors (Blut et al., 2016; Lai, 2015; Lariviere et al., 2014; Ram \& Wu, 2016) have argued that phenomena of loyalty and its drivers could highly depend on country's culture or level of development. Paparoidamis et al., (2017) have added that loyalty building is a contextspecific issue and might rely on the business traditions of a country. The Lithuanian B-2-B market is especially interesting for this research since it represents transition economies from Eastern Europe (Curi et al., 2016; Krasniqi \& Desai 2016). 
The aim of the paper is to evaluate a direct and mediated impact of main drivers on two types of loyalty (attitudinal and behavioural) for B-2-B markets.

Research method: a narrative analysis of the scientific literature (Cronin et al., 2008) was applied for developing the theoretical analysis. A survey with the two-step procedure was used for gathering empirical data; multivariate regression analysis and PROCESS regression plug-in with bootstrap 10000 was used for evaluation of the impact of drivers on satisfaction, attitudinal and behavioural loyalty.

\section{Theory and Hypothesis}

Loyalty is a complex concept, and initial understanding of loyalty as repurchase behaviour is expanded to a psychological meaning of the phenomena, related to the psychological attachment to an object (Bandyopadhyay \& Martell, 2007). DeMatos \& Rossi (2008) have noticed that unidimensional (behavioural) perception of loyalty is too narrow and could be influenced by some situational factors, which have an impact on customer's decision to use the same supplier (Caceres \& Paparoidamis, 2007). Attitudinal loyalty describes the customer's psychological attachment to a supplier (Rauyruen \& Miller, 2007). Cheng (2011) has stated that behavioural loyalty assures the conversion of customers' loyalty to sales, while attitudinal loyalty could have a positive effect on sales indirectly - through positive WOM. Some authors have concluded that behavioural and attitudinal loyalty are strongly related (Gecti \& Zengin, 2013, Huang \& Zhang, 2008), while other authors stated that attitudinal loyalty has a positive impact on behavioural loyalty (Caceres \& Paparoidamis, 2007; Russel-Bennet et al., 2007). By the information mentioned above, we claim the following:

$H_{l}$ Attitudinal loyalty has a positive impact on behavioural loyalty.

Authors have analysed numerous factors that could have an impact on customers' loyalty (Bardauskaite, 2014; Yang, 2015; Janita \& Miranda 2013). Among these factors, the authors have usually mentioned satisfaction, perceived quality, trust, commitment and switching costs.

Satisfaction was usually mentioned as the main factor, which influences customers' loyalty (Lam et al., 2004, Shi et al., 2011; Liu et al., 2011, Banyte et al., 2014). Satisfaction is perceived as a consequence of the customer's post-purchase evaluations of both tangible and intangible attributes of an object (Vazquez-Carrasco \& Foxall, 2006). Shi et al. (2011) have indicated the positive influences of satisfaction on loyalty. Satisfaction has a positive effect on the long-term relationships between customer and supplier (Lam et al., 2004) and increases purchasing intentions (Russel-Bennet, McColl-Kennedey \& Coote 2007). Satisfaction could also increase attitudinal loyalty through customer referrals (Oliver, 1993; Cheng, 2011). Thus, we hypothesize that: loyalty.

$\mathrm{H}_{2}$ : Customer satisfaction positively affects attitudinal

$H_{3}$ : Attitudinal loyalty mediates (at least partly) impact of customer satisfaction on behavioural loyalty.

Olsen (2002) has noticed that the perception of quality is closely related to satisfaction. According to Parasuraman, Berry \& Zeithalm (1993), the main difference between satisfaction and perceived quality lies in the place of purchasing process - satisfaction comes after purchasing a product, while perceived quality emerges before it. Customers have some expectations related to the functional and technical characteristics of a product (Caceres \& Paparoidamis, 2007). However, the importance of these characteristics might differ depending on the type of products (Gounaris, 2005). Technical aspects are more important for goods, since they are easily recognisable (Madu \& Madu, 2005), but functional features are more important for services. It is a rare case when B2B purchasing would include only the purchasing of goods. Thus, perceived functional quality seems to be a necessity rather than a sufficient condition for successful long-term relationships in B2B services (Briggs \& Grisaffe, 2010; Huang, Leu \& Farn 2008).

Moreover, perceived quality has an indirect impact on loyalty - through satisfaction (Vaidyanathan \& Devaraj (2008). Therefore we expect that:

$\mathrm{H}_{4}$ : Satisfaction mediates impact of perceived quality on loyalty.

Some authors state that customers continue to work with a supplier because of high switching costs. Switching costs could be both financial costs (Woisetschlager et al. 2011) and psychological inconvenience, related to the change of a supplier (Barroso \& Picon, 2012). If switching costs are high, a firm may bear more costs to change an existing partner, and is thus more inclined to maintain existing relationships (Kim et al., 2010). Lam et al., (2004). Provided that everything else being the same, customers will be motivated to stay in the current relationship to minimize switching costs. Shi et al. (2011), Woisetschlager, Lentz \& Evanschitzky (2011) have stated that switching costs was one of the most important drivers of loyalty. However, a part of switching barriers could be perceived as natural or even positive, since they arise from the customer's side (Egan, 2001). Another part of these costs could have a negative attitude, since they were created by a supplier, like time requirements or penalties (Vazquez-Carrasco \& Foxall, 2006). Based on this, we suppose that:

$H_{5}$ : Switching costs have a negative impact on attitudinal loyalty.

$H_{6}$ : Switching costs have a positive impact on behavioural loyalty.

When the relationship between customer and vendor is considered important or it is desired to continue indefinitely, commitment appears (Friman et al., 2002; Morgan \& Hunt, 1994). Gounaris (2005) divides commitment into deducted and emotional. Fullerton (2011), Hur, Park \& Kim (2010) have stated that emotional attachment has a stronger impact on loyalty than deducted one. However, Inoue, Funk \& McDonald (2017) have found that commitment had a week negative impact on behavioural loyalty. In line with that, Mpinganjira, Roberts-Lombard \& Svensson (2017) have discovered that commitment had an impact on satisfaction and it had a stronger correlation with non-economic than economic satisfaction. Importance of commitment for satisfaction was found by many studies (Farrelly \& Quester, 2005; Johnson, Sivadas \& Garbarino, 2008). Farrelly \& Quester (2005) have noted that evidence of high-level commitment should lead to higher levels of satisfaction with the relationship. Therefore, we assume that:

$H_{7}$ : Satisfaction mediates (at least partly) impact of commitment on attitudinal loyalty. 
Morgan \& Hunt (1994) have pointed out that trust exists when one party has confidence in reliability and integrity of its exchange partner. Thus, a trust could be vital for having long-term relationships between buyers and suppliers (McKnight \& Chervany, (2001). Many authors have confirmed the importance of trust in business relationships (Denize \& Young, 2007; Seppänen, Blomqvist \& Sunqvist, 2007; Young, 2006). Chen (2006) has separated trust into two categories: 1) trust as belief, attitude or expectation towards another party; or 2) trust as behavioural intention. Since trust could be found as expectation towards another party, some authors (Gummerus et al., 2004; Denga et al., 2010) have found it to be an important driving factor for customer satisfaction. In addition, Mpinganjira, RobertsLombard \& Svennson (2017) have noticed a positive relationship between trust and both economical and noneconomical satisfaction. Other authors (Aurier \& N'Goala, 2010; Theron, Terblanche, \& Boshoff, 2008) have stated that trust mediates the entire impact of satisfaction on longterm relationships. Such results show that trust can work as a consequence of previous relations with a supplier and have an influence on attitudinal loyalty. However, trust can work as a behaviour intention as well. Aurier \& N'Goala (2010) have reported that trust directly influences service usage and cross-buying, while some studies have found a direct relationship between trust and loyalty (Carter et al., 2014; Paparoidamis, Katsikeas \& Chumpitaz, 2017; Jan \& Abdullah, 2014). On the basis of these findings, we assume the following:

$H_{8}$ : Satisfaction mediates (at least partly) impact of trust on loyalty.

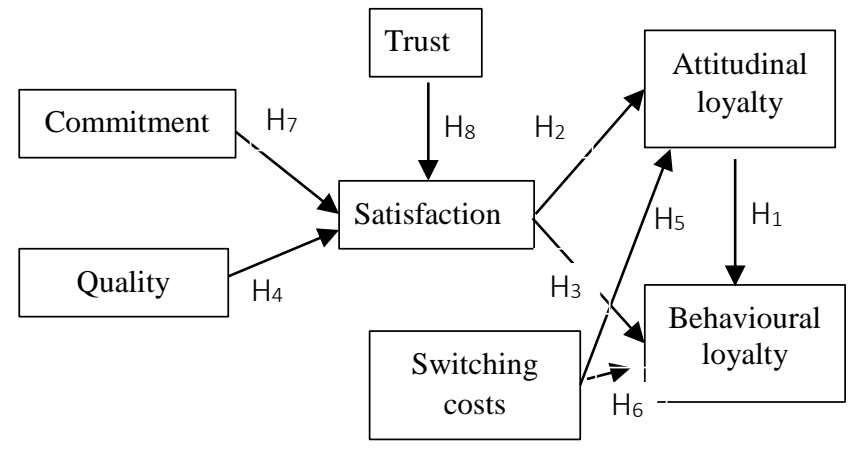

Figure 1. Conceptual Framework

\section{Research Methodology}

The subject of the survey were clients of a company, which is a representative of a global automotive glass repair and replacement company. It supplies vehicle glass for car services and repairs or replaces them in a local market.

The research instrument included several scales for measurement of selected variables. One scale (five statements) was used for analysis of satisfaction. The statements were taken from Ping (1993) and Lam et al. (2004), and high reliability was noticed (Cronbach's alpha $\alpha=0.941$ ). Another two dependent variables were attitudinal and behavioural loyalty. Four statements for measurement of attitudinal loyalty and five for behavioural loyalty were adapted from Cronin, Brady \& Hult (2000), Zeithaml, Berry \& Parasurman (1993) and Lam et al. (2004). Both scales were reliable ( $\alpha=0.927$ for attitudinal and $\alpha=0.889$ behavioural loyalty). Several variables were treated as independent variables. Perceived quality was measured by five statements, adapted from Hallikas et al. (2014) and Parasuraman, Berry $\&$ Zeithalm (1993) $(\alpha=0.827)$. Another scale was used for the evaluation of trust. It had four statements, taken from Liu, Guo \& Le (2011) and Fullerton (2011) $(\alpha=0.901)$. Five statements were used for measurement of switching costs, which were adapted from Lam et al. (2004) and Fullerton (2011) and had reasonable reliability $(\alpha=0.900)$. Finally, the commitment was evaluated, using four statements, adapted from Pan, Sheng \& Xie (2012) and Fullerton (2011), which had excellent reliability as well $(\alpha=0.830)$. All statements have been measured on a five-point Likert scale from 'totally disagree' to 'totally agree'.

The two-stage sampling procedure was applied for the selection of respondents. During the first step, respondents were selected by two criteria - clients had to be companies, and companies which have bought three and more times per year. Such selection enabled to choose clients, who have purchased repeatedly. A sample contained 358 companies. Since companies had a number of employees, it was essential to find a correct employee, who would have an experience of working with a vendor. All companies were contacted, and the right person was selected in each company. Depending on a company's size, directors, managers or supply managers were selected as respondents. Each respondent was invited to take part in a survey by phone. 284 respondents agreed to participate in a survey. During the second stage, the data collection was performed by internet survey. 105 responses were collected, or response rate was $37 \%$, which is quite typical for business studies (Alejandro et al., 2011; Caceres \& Paparoidamis, 2007; Eggert \& Helm 2001). In addition, four questionnaires were filled incorrectly. Thus 101 responses were used for further analysis.

The distribution of respondents is presented in Table 1. Due to the specifics of the company, the main part of respondents were companies, performing transportation services (both cargoes and people). Other two large groups were car-services and car leasing and insurance companies. Finally, $27 \%$ of companies were retailing, wholesaling or manufacturing companies, which had a big fleet of cars. Distribution of respondents according to the size of a company was almost equal. Participating companies were customers of the vendor for 4.07 years on average. Just $9 \%$ of respondents were women due to business specifics. Age of respondents was 41.66. More than half of respondents $(56 \%)$ were directors, $25 \%$ were managers and $19 \%$ technical personnel.

Table 1

Distribution of Participating Companies, \%

\begin{tabular}{|l|l|l|l|l|l|}
\hline \multicolumn{1}{|c|}{ Activity } & $\%$ & \multicolumn{1}{c|}{$\begin{array}{c}\text { No of } \\
\text { employees }\end{array}$} & $\%$ & Gender & $\%$ \\
\hline Transportation & 38.5 & Less than 50 & 37.6 & Men & 91 \\
\hline $\begin{array}{l}\text { Leasing, } \\
\text { insurance }\end{array}$ & 17.7 & $50-249$ & 31.7 & Women & 9 \\
\hline Car-service & 16.7 & 250 and more & 30.7 & & \\
\hline Other & 27.1 & & & & \\
\hline
\end{tabular}




\section{Findings}

The main issue of the research was to identify the factors, which have an influence on customers' intention to repeat purchasing from a supplier. Out of the selected 6 factors (attitudinal loyalty, satisfaction, trust, switching costs, commitment, and quality), just the first four influenced customers' behavioural loyalty $\left(\mathrm{R}^{2}=0.81, \mathrm{~F}(6)=63.86\right.$, $\mathrm{p}<0.001)$. Two most influential factors on behavioural loyalty were attitudinal loyalty $(\mathrm{t}=3.99, \mathrm{p}=0.000)$ and satisfaction $(\mathrm{t}=3.95, \mathrm{p}=0.000)$ (see Table 2). However, the high value of VIF for satisfaction suppose that attitudinal loyalty and satisfaction are highly related, which means satisfaction could have an indirect impact on behavioural loyalty. To check the mediation impact of attitudinal loyalty on satisfactionbehavioural loyalty relationship (as well as other mediation effects), the PROCESS regression plug-in with bootstrap 10000 was used (Hayes, 2013). Analysis of the mediation of attitudinal loyalty showed that a partial mediation exists. Satisfaction had direct influence on behavioural loyalty
( $c^{\prime}=0.6576,95 \%$ CI [0.4625, 0.8527], $\left.\mathrm{t}=6.69, \mathrm{p}<0.0001\right)$. In addition, satisfaction had indirect influence on dependent variable through the mediator - attitudinal loyalty $(a * b=0.3737,95 \%$ CI $[0.1993,0.6011])$. The mediation effect was strong and statistically significant $(Z=4.49$, $\mathrm{p}<0.001, \mathrm{R}^{2}{ }_{\text {med }}=0.60$ ). So, we can accept hypotheses $\mathrm{H}_{1}$ and $\mathrm{H}_{3}$. Such results go in line with the findings of the previous authors (Gecti \& Zengin, 2013, Huang \& Zhang, 2008; Caceres \& Paparoidamis, 2007; Russel-Bennet, McColl - Kennedy \& Coote, 2007).

Trust was another influential factor $(\mathrm{t}=2.80, \mathrm{p}=0.006)$. Such a result confirms the findings of the previous studies (Aurier \& N'Goala, 2010). Thus, we can conclude that intention to rely on a supplier's ability to fulfill its implicit and explicit promises plays an important role for B-2-B environment. Finally, the results proved that switching costs has a positive effect $(\mathrm{t}=2.68, \mathrm{p}=0.009)$ on an intention to continue business with an existing supplier. It supports $\mathrm{H}_{6}$ and the findings of Shi, Chen \& Ma (2011), Woisetschlager, Lentz \& Evanschitzky (2012).

Table 2

Factors, Influencing Behavioural Loyalty

\begin{tabular}{|l|c|c|c|c|c|c|}
\hline \multirow{2}{*}{} & \multicolumn{2}{|c|}{ Unstandardized Coefficients } & \multirow{2}{*}{$\begin{array}{c}\text { Standardized } \\
\text { Coefficients }\end{array}$} & \multirow{2}{*}{$\mathrm{t}$} & \multirow{2}{*}{$\begin{array}{c}\text { Collinearity } \\
\text { Statistics }\end{array}$} \\
\cline { 2 - 7 } & $\mathrm{B}$ & Std. Error & Beta & & \multicolumn{2}{c|}{ VIF } \\
\hline (Constant) & -0.639 & 0.302 & & -2.114 & 0.037 & \\
\hline Attitudinal loyalty & 0.379 & 0.095 & 0.331 & 3.992 & 0.000 & 3.252 \\
\hline Satisfaction & 0.441 & 0.112 & 0.360 & 3.952 & 0.000 & 3.917 \\
\hline Commitment & 0.062 & 0.070 & 0.072 & 0.885 & 0.379 & 3.106 \\
\hline Perceived switching costs & 0.080 & 0.039 & 0.119 & 2.054 & 0.043 & 1.581 \\
\hline Perceived quality & 0.004 & 0.096 & 0.003 & 0.041 & 0.967 & 2.499 \\
\hline Trust & 0.189 & 0.092 & 0.167 & 2.067 & 0.042 & 3.097 \\
\hline
\end{tabular}

As was expected, and corresponding to the theory of planned behaviour, attitudinal loyalty had a very strong impact on behavioural loyalty. Therefore, we should understand, which factors create customers' attitudinal loyalty. Three out of five analysed factors had an impact on attitudinal loyalty $\left(\mathrm{R}^{2}=0.69, \mathrm{~F}(5)=41.61, \mathrm{p}<0.001\right)$ (see Table 3). In line with this theory, we have found that the most important factor for creating attitudinal loyalty is satisfaction ( $\mathrm{t}=5.80, \mathrm{p}=0.000)$. Thus we can accept $\mathrm{H}_{2}$.

Some authors have stated that commitment will have an impact on loyalty (Bardauskaite, 2014). The results proved the expectation that commitment had an impact on attitudinal loyalty $(\mathrm{t}=2.698, \mathrm{p}=0.008)$. These results prove Mpinganjira et al., (2017) findings that commitment is more related to the perception than to the real behavioural intentions. Switching costs influenced attitudinal loyalty as well, and this supports the findings of Woisetschlager, Lentz \& Evanschitzky (2012). Switching costs has a negative impact on attitudinal loyalty in contrast to behavioural loyalty $\left(\mathrm{H}_{5}\right.$ is proved). As Vazquez-Carrasco \& Foxall (2006) have stated, high switching costs could have a negative impact on the perception of a supplier.

Factors, Influencing Attitudinal Loyalty

Table 3

\begin{tabular}{|l|c|c|c|c|c|c|}
\hline \multirow{2}{*}{} & \multicolumn{2}{|c|}{ Unstandardized Coefficients } & \multirow{2}{*}{$\begin{array}{c}\text { Standardized } \\
\text { Coefficients }\end{array}$} & \multirow{2}{*}{$\mathrm{t}$} & \multirow{2}{*}{$\begin{array}{c}\text { Sig. } \\
\text { Statistics }\end{array}$} \\
\cline { 2 - 7 } & $\mathrm{B}$ & Std. Error & Beta & & \multicolumn{2}{c|}{ VIF } \\
\hline (Constant) & 0.469 & 0.328 & & 1.431 & 0.156 & \\
\hline Satisfaction & 0.603 & 0.104 & 0.562 & 5.805 & 0.000 & 2.809 \\
\hline Commitment & 0.201 & 0.074 & 0.265 & 2.698 & 0.008 & 2.893 \\
\hline Trust & 0.117 & 0.099 & 0.120 & 1.183 & 0.240 & 3.069 \\
\hline Perceived quality & 0.063 & 0.105 & 0.054 & 0.596 & 0.553 & 2.495 \\
\hline Perceived switching costs & -0.094 & 0.042 & -0.160 & -2.266 & 0.026 & 1.489 \\
\hline
\end{tabular}

The final part of the research was related to the analysis of factors that could have an impact on customers' satisfaction. Two factors had an impact on satisfaction $\left(\mathrm{R}^{2}=0.63, \mathrm{~F}(2)=82.96\right.$, $\left.\mathrm{p}<0.001\right)$ (see Table 4). Quality perception had a strong influence on satisfaction $(\mathrm{t}=6.878$, $\mathrm{p}=0.000)$, which supposes that quality had only an indirect impact on behavioural and attitudinal loyalty. The PROCESS regression was used for analysis of the direct and indirect impact of quality on behavioural and attitudinal loyalty. Perceived quality had no direct influence on attitudinal loyalty $\left(c^{\prime}=0.1782,95 \%\right.$ CI $[-0.0257,0.3821]$, $\mathrm{t}=1.7349, \mathrm{p}=0.0859)$ or behavioural loyalty $\left(\mathrm{c}^{\prime}=0.1519,95\right.$ 
\% CI [-0.0506, 0.3545], $\mathrm{t}=1.4885, \mathrm{p}=0.1399)$. However perceived quality had indirect influence on both types of loyalty through the mediator - satisfaction (attitudinal $(\mathrm{a} * \mathrm{~b}=0.5613,95 \%$ CI $[0.3528,0.809])$ and behavioural $(a * b=0.7242,95 \%$ CI $[0.518,0.979]))$. The mediation effect was strong and statistically significant (attitudinal loyalty $\mathrm{Z}=6.08, \mathrm{p}<0.001, \mathrm{R}^{2} \_$med $=0.40$ and behavioural loyalty $\left.\mathrm{Z}=7.05, \mathrm{p}<0.001, \quad \mathrm{R}^{2}{ }_{-\operatorname{med}}=0.43\right)$. Such results indicate full mediation and support $\mathrm{H}_{4}$

The results show that commitment had a strong impact on satisfaction $(\mathrm{t}=5.518, \mathrm{p}=0.000)$. Such results go in line with the results of other authors (Farrelly \& Quester, 2005; Johnson et al., 2008). However, the commitment had no direct impact on behavioural loyalty (see Table 2), which means that commitment had an indirect impact on behavioural loyalty (through satisfaction). In the case of attitudinal loyalty, the commitment had a direct and indirect impact on it. To check the mediation impact of satisfaction on commitment - attitudinal loyalty relationship, the PROCESS regression plug-in with bootstrap 10000 was used (Hayes, 2013). Analysis of the mediation impact of satisfaction showed that a partial mediation. Commitment had direct influence on attitudinal loyalty $\left(c^{\prime}=0.1982,95 \%\right.$ CI $[0.0778,0.3185], \mathrm{t}=3.27, \mathrm{p}=0.0015)$. In addition, commitment had indirect influence on dependent variable through the mediator - satisfaction $\left(\mathrm{a}^{*} \mathrm{~b}=0.3101,95 \%\right.$ CI $[0.2178,0.4192])$. The mediation effect was strong and statistically significant $\left(Z=5.78, p<0.001, R^{2} \_\right.$med $\left.=0.41\right)$. So we can conclude that hypothesis $\mathrm{H}_{7}$ was proved.

Factors, Influencing Satisfaction

\begin{tabular}{|c|c|c|c|c|c|c|}
\hline & \multicolumn{2}{|c|}{ Unstandardized Coefficients } & \multirow{2}{*}{$\begin{array}{c}\text { Standardized Coefficients } \\
\text { Beta }\end{array}$} & \multirow{2}{*}{$\mathrm{t}$} & \multirow{2}{*}{ Sig. } & \multirow{2}{*}{$\begin{array}{c}\begin{array}{c}\text { Collinearity } \\
\text { Statistics }\end{array} \\
\text { VIF }\end{array}$} \\
\hline & B & Std. Error & & & & \\
\hline (Constant) & 0.889 & 0.315 & & 2.818 & 0.006 & \\
\hline Perceived quality & 0.474 & 0.093 & 0.438 & 5.117 & 0.000 & 1.922 \\
\hline Trust & 0.147 & 0.097 & 0.160 & 1.521 & 0.132 & 2.900 \\
\hline Perceived switching costs & -0.007 & 0.042 & -0.013 & -0.177 & 0.860 & 1.474 \\
\hline Commitment & 0.230 & 0.068 & 0.330 & 3.388 & 0.001 & 2.492 \\
\hline
\end{tabular}

To check the mediation impact of satisfaction on trust loyalty relationship, the PROCESS regression plug-in with bootstrap 10000 was used (Hayes, 2013). Analysis of the mediation impact of satisfaction showed that a partial mediation existed. Trust had direct influence on attitudinal loyalty $\left(c^{\prime}=0.2452,95 \%\right.$ CI $[0.0809,0.4095], t=2.96$, $\mathrm{p}=0.0038)$ and on behavioural loyalty $\left(\mathrm{c}^{\prime}=0.3487,95 \% \mathrm{CI}\right.$ $[0.1905,0.5068], \mathrm{t}=4.3756, \mathrm{p}<0.0001)$. In addition, trust had indirect influence on dependent variable through the mediator - satisfaction (attitudinal loyalty $(\mathrm{a} * \mathrm{~b}=0.4216,95$ $\%$ CI $[0.2782,0.5893])$ and behavioural loyalty $(a * b=0.5054,95 \%$ CI [0.3126, 0.7119])). The mediation effect was stronger than direct effect and statistically significant (attitudinal loyalty $\mathrm{Z}=5.80, \quad \mathrm{p}<0.001$, $\mathrm{R}^{2}$ _med $=0.43$; behavioural loyalty $\mathrm{Z}=6.607$, $\mathrm{p}<0.001$, $\mathrm{R}^{2} \_$med $=0.51$ ). Thus, we can conclude that hypothesis $\mathrm{H}_{8}$ was proved.

\section{Discussions and Conclusions}

The research aimed to find out which of the factors satisfaction, trust, switching costs, commitment, and quality, - have the biggest impact on attitudinal and behavioural loyalty in the B2B market. The B2B environment was chosen for the research due to a small number of previous studies on attitudinal and behavioural loyalty aspects, conducted in a B2B context. A narrative analysis of past surveys has shown that all these factors are important for increasing customer loyalty in the B2B market. High coefficients of determination proved the importance of the selected variables for the determination of the main drivers of loyalty. However, these drivers acted in a quite different way, depending on the type of loyalty. The performed analysis supported all hypothesized relationships. It has emerged that different factors had an impact on behavioural and attitudinal loyalty. Attitudinal loyalty, trust, perceived switching costs have confirmed their importance for customers' repeat purchase. Meanwhile, attitudinal loyalty is driven by satisfaction, commitment and perceived switching costs.

Satisfaction. Satisfaction has been found to be the most relevant to attitudinal loyalty. The analysis reveals that acting through attitudinal loyalty, satisfaction affects behavioural loyalty, which supports previous findings (Banyte, Tarute \& Taujinskyte, 2014; Liu, Guo \& Le, 2011). However, it should be noted that satisfaction also has a direct impact on behavioural loyalty. It means that, by splitting the attitudinal and behavioural loyalty, more accurate research results can be obtained.

Switching costs. Switching costs have a negative effect on attitudinal loyalty, but their impact on behavioural loyalty is a positive one. That means that rising switching costs will force consumers to buy, but switching costs were negatively related to attitude towards the supplier. Thus, the business participants should also keep in mind the finding of the research, that an increase in the switching costs might have a negative influence on emotional attachment to suppliers.

Trust. The study has shown that trust has a direct impact on attitudinal loyalty. It is important to note, however, that trust also has an indirect effect on both types of loyalty through the mediation of satisfaction. Such results confirm the findings of the previous studies (Vaidyanathan \& Devaraj, 2008). Satisfaction as mediator was important for trust - loyalty relationship as well. Even though just partial mediation was noticed in this case, but the indirect effect of trust on attitudinal loyalty was stronger than the direct effect. The importance of trust on loyalty confirms the findings of the previous studies (Paparoidamis, Katsikeas, Chumpitaz, 2017; Denga et al., 2010; Mpinganjira, Roberts-Lombard \& Svensson, 2017, Banyte, Tarute \& Taujinskyte 2014). It implies that suppliers' ability to fulfill their promises is 
essential for repeat purchases in business practice. Therefore, the B-2-B service companies should keep in mind that the promises for repeat purchase are paved before it, e.g., during negotiations, making an agreement, etc.

Perceived quality. As the analysis shows, perceived quality does not have a direct impact on loyalty. However, it had an indirect influence on loyalty through the mediator satisfaction. Such results confirm the findings of the previous studies (Vaidyanathan \& Devaraj, 2008). This means that the better the consumer values the quality, the higher the satisfaction, which in itself might mean a favourable attitude towards the supplier and positive effect on the purchase behaviour.

Commitment. The commitment had a strong direct impact on attitudinal loyalty, but an indirect effect on attitudinal loyalty (through satisfaction) was even stronger. However, the commitment had no direct impact on behavioural loyalty, which goes in line with the results of Mpinganjira, Roberts-Lombard \& Svensson (2017). Thus, we can conclude that commitment is more related to the perception than to the real behavioural intentions.

Overall, both types of loyalty are affected by satisfaction and trust. By analysing the attitudinal and behavioural loyalty from different perspectives, it has emerged that attitudinal loyalty is directly affected by satisfaction, commitment, and trust, while the greatest impact on behavioural loyalty have come from switching costs and satisfaction. The study shows that perceived quality has no direct impact on loyalty, but due to the perceived quality impact on satisfaction, its relationships with loyalty are intensifying. It is important to note that satisfaction, acting as a mediating factor, strengthens the impact of other factors on both types of loyalty, which was analysed in the studies of other scholars.

Despite the contributions of this study, some research limitations must be noticed. The research was limited to one business area - transport-related B-2-B companies. Such limitations suggest an opportunity for researching different industries. This study is subject to geographical limitation as well since it was performed only in Lithuania. There is a risk that due to different countries and continents with their respective business environments, the attributes, which are perceived as important for their relationship to behavioural and attitudinal loyalty, might also differ. Therefore, it is recommended to conduct a cross-cultural analysis of these factors and their impact on both types of loyalty in a B2B setting.

\section{References}

Alejandro, T. B., Souza, D. V., Boles, J. S., Ribeiro, A. H. P., \& Monteiro, P. R. R. (2011). The outcome of company and account manager relationship quality on loyalty, relationship value and performance. Industrial Marketing Management, 40(1), 36-43. https://doi.org/10.1016/j.indmarman.2010.09.008

Askariazad, M. H., \& Babakhani, N. (2015). An application of European Customer Satisfaction Index (ECSI) in business to business (B2B) context. Journal of Business \& Industrial Marketing, 30(1), 17-31. https://doi.org/10.1108/JBIM07-2011-0093

Aurier, P., \& N'Goala, G. (2010). The differing and mediating roles of trust and relationship commitment in service relationship maintenance and development. Journal of the Academy of Marketing Science, 38(3), 303-325. https://doi.org/10.1007/s11747-009-0163-z

Bandyopadhyay, S., \& Martell, M. (2007). Does attitudinal loyalty influence behavioral loyalty? A theoretical and empirical study. Journal of Retailing and Consumer Services 14 (1), 35-44. https://doi.org/10.1016/j.jretconser.2006.03.002

Banyte, J., Tarute, A., \& Taujanskyte, I. (2014), Customer engagement into value creation: determining factors and relations with loyalty. Inzinerine Ekonomika-Engineering Economics, 25 (5), 568-577. https://doi.org/10.5755/j01.ee.25. 5.8402

Bardauskaite, I. (2014). Loyalty in the Business-to-Business Service Context: A Literature Review and Proposed Framework. Journal of Relationship Marketing, 13 (1), 28-69. https://doi.org/10.1080/15332667.2014.882628

Barroso, C., \& Picon, A. (2012). Multi-dimensional analysis of perceived switching costs. Industrial Marketing Management, 41 (3), 531-543. https://doi.org/10.1016/j.indmarman.2011.06.020

Biedenbach, G., Bengtsson, M., \& Marell, A. (2015). Brand equity, satisfaction, and switching costs: An examination of effects in the business-to-business setting. Marketing Intelligence \& Planning, 33(2), 164-178. https://doi.org/10. 1108/MIP-03-2014-0059

Blut, M., Evanschitzky, H., Backhaus, C., Rudd, J., \& Marck, M. (2016). Securing Business-to-business Relationships: The Impact of Switching Costs. Industrial Marketing Management 52, 82-90. https://doi.org/10.1016/ j.indmarman.2015.05.010

Briggs, E., \& Grisaffe, D. (2010). Service performance-loyalty link in a business-to-business context: The role of relation exchange outcomes and customer characteristics. Journal of Service Research, 13(1), 37-51. https://doi.org/10.1177/ 1094670509345683

Caceres, Ch. R., \& Paparoidamis, G. (2007). Service quality, relationship satisfaction, trust, commitment and business-tobusiness loyalty. European Journal of Marketing, 41 (7/8), 836-867. https://doi.org/10.1108/03090560710752429

Carter, M., Wright, R., Thatcher, J. B., \& Klein, R. (2014). Understanding online customers' ties to merchants: the moderating influence of trust on the relationship between switching costs and e-loyalty. European Journal of Information Systems 23, 185-204. https://doi.org/10.1057/ejis.2012.55 
Caruana, A., \& Ewing, M. T. (2010). How corporate reputation, quality, and value influence online loyalty, Journal of Business Research, 63(9/10), 1103-1110. https://doi.org/10.1016/j.jbusres.2009.04.030

Cater, T., \& Cater, B. (2010). Product and relationship quality influence on customer commitment and loyalty in B2B manufacturing relationships. Industrial Marketing Management, 39(8), 1321-1333. https://doi.org/10.1016/ j.indmarman.2010.02.006

Chen, C. (2006). Identifying significant factors influencing consumer trust in an online travel site. Information Technology \& Tourism, 8(3/4), 197-214. https://doi.org/10.3727/109830506778690849

Cheng, S. I. (2011). Comparisons of Competing Models between Attitudinal Loyalty and Behavioral Loyalty. International Journal of Business and Social Science, 2 (10), 149-166.

Cronin, J. J. Jr., Brady, M. K., \& Hult, G. T. (2000). Assessing the effects of quality, value, and customer satisfaction on consumer behavioral intentions in service environments. Journal of Retailing, 76(2), 193-218. https://doi.org/10. 1016/S0022-4359(00)00028-2

Cronin, P., Ryan, F., \& Coughlan, M. (2008). Undertaking a literature review: a step-by-step approach. British journal of nursing, 17(1), 38-43. https://doi.org/10.12968/bjon.2008.17.1.28059

Curi, C., Gedvilas, J., \& Lozano-Vivas, A. (2016). Corporate governance of SOEs and performance in transition countries. Evidence from Lithuania. Bozen Economics \& Management, 36, 1-28.

DeMatos, C. A., \& Rossi, C. A. V. (2008).Word-of-mouth communications in marketing: a meta-analytic review of the antecedents and moderators. Journal of the Academy of Marketing Science, 36(4), 578-596. https://doi.org/10. 1007/s11747-008-0121-1

Denga, Z., Lua, Y., Weib, K. K., \& Zhanga, J. (2010). Understanding customer satisfaction and loyalty: An empirical study of mobile instant messages in China. International Journal of Information Management 30, $289-300$. https://doi.org/10.1016/j.ijinfomgt.2009.10.001

Denize, S., \& Young, L. (2007). Concerning trust and information. Industrial Marketing Management, 36(7), 968-982. https://doi.org/10.1016/j.indmarman.2007.06.004

Ding, D. X., Hu, P. J. H., \& Sheng, O. R. L. (2011). e-SELFQUAL: a scale for measuring online self-service quality, Journal of Business Research, 64(5), 508-515. https://doi.org/10.1016/j.jbusres.2010.04.007

Egan, J. (2001). Relationship Marketing. Exploring Relational Strategies in Marketing. 1st edition London: Financial Times / Prentice Hall. Book.

Eggert, A., \& Helm, S. (2003). Exploring the impact of relationship transparency on business relationships: A crosssectional study among purchasing managers in Germany. Industrial Marketing Management, 32(2), 101-108. https://doi.org/10.1016/S0019-8501(02)00224-9

El-Manstrly, D. (2016). Enhancing customer loyalty: critical switching cost factors. Journal of Service Management, 27(2), 144-169. https://doi.org/10.1108/JOSM-09-2015-0291

Evanschitzky, H., Iyer, Gr., Plassmann, H, Niessing, J., \& Meffert, H. (2006). The relative strength of affective commitment in securing loyalty in service relationships. Journal of Business Research, 59(12), 1207-1213. https://doi.org/10. 1016/j.jbusres.2006.08.005

Farrelly, F. J., \& Quester, P. G. (2005). Examining important relationship quality constructs of the focal sponsorship exchange, Industrial Marketing Management, 34(1), 211-219. https://doi.org/10.1016/j.indmarman.2004.09.003

Friman, M., Garling, T., Millett, B., Mattsson, J., \& Johnston, R. (2002). An analysis of international business-to-business relationships based on the commitment-trust theory. Industrial Marketing Management, 31(5), 403-409. https://doi.org/10.1016/S0019-8501(01)00154-7

Fullerton, G. (2011). Creating advocates: The roles of satisfaction, trust and commitment. Journal of Retailing and Consumer Services, 18(1), 92-100. https://doi.org/10.1016/j.jretconser.2010.10.003

Gassmann, M. M. K., \& Oliver, G. (2011). How do foreign R\&D units in China manage their Chinese R\&D staff? An empirical exploration. International Journal of Technology Management, 56(1), 73-91. https://doi.org/10.1504/ IJTM.2011.042459

Geçti, F., \& Zengin, H. (2013). The Relationship between brand trust, brand affect, attitudinal loyalty and behavioral loyalty: a field study towards sports shoe consumers in Turkey. International Journal of Marketing Studies, 5 (2), 111-119. https://doi.org/10.5539/ijms.v5n2p111

Gounaris, S. P. (2005). Trust and commitment influences on customer retention: insights from business-to-business services. Journal of Business Research, 58(2), 126- 140. https://doi.org/10.1016/S0148-2963(03)00122-X

Gummerus, J., Liljander, V., Pura, M., \& Riel, A. V. (2004). Customer loyalty to content-based web sites: the case of an online health-care service. Journal of Services Marketing, 18(3), 175-186. https://doi.org/10.1108/08876 040410536486 
Hayes, A. F. (2013). Introduction to mediation, moderation, and conditional process analysis: A regression-based approach. New York: Guilford Press.

Hallikas, J., Immonen, M., Pynnonen, M., \& Mikkonen, K. (2014). Service purchasing and value creation: towards systemic purchases, International Journal of Production Economics, 147 (7), 53-61. https://doi.org/10.1016/j.ijpe.2012.10.005

Huang, J., \& Zhang, D. (2008). Customer value and brand loyalty: Multi-dimensional empirical test. International Seminar on Future Information Technology and Management Engineering, 20 Nov., Leicestershire, United Kingdom, Loughborough. 102-106. https://doi.org/10.1109/FITME.2008.84

Huang, L. T., Leu, J. D., \& Farn, C. K. (2008). Factors affecting customer loyalty to application service providers in different levels of relationships. European Conference on Information Systems (ECIS). Galway, Ireland. $37-48$.

Hur, W. M., Park, J., \& Kim, M. (2010). The role of commitment on the customer benefits-loyalty relationship in mobile service industry. Service Industries Journal, 30(14), 2293-2309. https://doi.org/10.1080/02642060802629877

Inoue, Y., Funk, D. C., \& McDonald, H. (2017). Predicting behavioral loyalty through corporate social responsibility: The mediating role of involvement and commitment. Journal of Business Research, 75, 46-56. https://doi.org/10.1016/ j.jbusres.2017.02.005

Jan, M. T., \& Abdullah, K. (2014). The impact of technology CSFs on customer satisfaction and the role of trust: An empirical study of the banks in Malaysia. International Journal of Bank Marketing, 32(5), 429-447. https://doi.org/10.1108/IJBM-11-2013-0139

Janita M. S., \& Miranda F. J. (2013). The antecedents of client loyalty in business-to-business (B2B) electronic marketplaces. Industrial Marketing Management, 42(5), 814-823. https://doi.org/10.1016/j.indmarman.2013.01.006

Johnson, M. S., Sivadas, E., \& Garbarino, E. (2008). Customer satisfaction, perceived risk and affective commitment: an investigation of directions of influence. Journal of Services Marketing, 22(5), 353-362. https://doi.org/10.1108/088 76040810889120

Kim, K. K., Park, S. H., Ryoo, S. Y., \& Park, S. K. (2010). Inter-organizational cooperation in buyer-supplier relationships: Both perspectives. Journal of Business Research, 63(8), 863-869. https://doi.org/10.1016/j.jbusres.2009.04.028

Krasniqi, B. A., \& Desai, S. (2016). Institutional Drivers of High-growth Firms: Country-level Evidence from 26 Transition Countries. Small Business Economics. 47(4), 1075-1094. https://doi.org/10.1007/s11187-016-9736-7

Kumar, V., Pozza, I., \& Ganesh, J. (2013). Revisiting the satisfaction-loyalty relationship: Empirical generalizations and directions for future research. Journal of Retailing, 89, 246-262. https://doi.org/10.1016/j.jretai.2013.02.001

Lai, I. K. W. (2015). The Roles of Value, Satisfaction, and Commitment in the Effect of Service Quality on Customer Loyalty in Hong Kong-Style Tea Restaurants. Cornell Hospitality Quarterly, 56(1), 118-138. https://doi.org/10.1177/ 1938965514556149

Lam, S. Y., Shankar, V., Erramilli, M. K., \& Murthy, B. (2004). Customer value, satisfaction, loyalty, and switching costs: an illustration from a business-to-business service context. Journal of the Academy of Marketing Science, 32(3), 293311. https://doi.org/10.1177/0092070304263330

Lariviere, B., Keiningham, T. L., Cooil, B., Aksoy, L., \& Malthouse, E. C. (2014). A longitudinal examination of customer commitment and loyalty. Journal of Service Management, 25(1), 75-100. https://doi.org/10.1108/JOSM-01-20130025

Liu, C. T., Guo, Y. M., \& Le, C. H. (2011). The effects of relationship quality and switching barriers on customer loyalty. International Journal of Information Management, 31, 71-79. https://doi.org/10.1016/j.ijinfomgt.2010.05.008

Madu, Ch. N., \& Madu, A. A. (2005). Dimensions of e-quality. International Journal of Quality \& Reliability Management, 19 (3), 246-258. https://doi.org/10.1108/02656710210415668

McKnight, D., \& Chervany, N. (2001). What trust means in e-commerce customer relationships: an interdisciplinary conceptual typology. International Journal of Electronic Commerce 6(2), 33-57. https://doi.org/10.1080/1086 4415.2001.11044235

Morgan, R. M., \& Hunt, S. D. (1994). The commitment-trust theory of relationship marketing. Journal of Marketing, 58(3), 20-38. https://doi.org/10.1177/002224299405800302

Mpinganjira, M., Roberts-Lombard, M., \& Svensson, G. (2017). Validating the relationship between trust, commitment, economic and non-economic satisfaction in South African buyer-supplier relationships. Journal of Business \& Industrial Marketing, 32(3), 421-431. https://doi.org/10.1108/JBIM-04-2015-0073

Oliver, R. (1993). Cognitive, affective and attribute bases of the satisfaction response. Journal of Consumer Research, 20, 418-430. https://doi.org/10.1086/209358

Olsen, S. O. (2002). Comparative Evaluation and the Relationship between Quality, Satisfaction, and Repurchase Loyalty. Journal of the Academy of Marketing Science, 30(3), 240-249. https://doi.org/10.1177/0092070302303005 
Pan, Y., Sheng, S., \& Xie, F. (2012). Antecedents of customer loyalty: An empirical synthesis and re-examination, Journal of Retailing and Consumer Services, 19(1), 150-158. https://doi.org/10.1016/j.jretconser.2011.11.004

Paparoidamis, N. G., Katsikeas, C. S., \& Chumpitaz, R. (2017). The role of supplier performance in building customer trust and loyalty: A cross-country examination. Industrial Marketing Management. 1-15. https://doi.org/10.1016/ j.indmarman.2017.02.005

Parasuraman, A., Berry, L. L., \& Zeithaml, V. A. (1993). More on improving service quality measurement. Journal of Retailing, 69(1), 140-147. https://doi.org/10.1016/S0022-4359(05)80007-7

Ping, R. A. (1993). The effects of satisfaction and structural constraints on retailer exiting, voice, loyalty, opportunism, and neglect. Journal of Retailing, 69(3), 320-352. https://doi.org/10.1016/0022-4359(93)90010-G

Ram, J., \& Wu, M. L. (2016). A fresh look at the role of switching cost in influencing customer loyalty: Empirical investigation using structural equation modelling analysis. Asia Pacific Journal of Marketing and Logistics, 28(4), 616-633. https://doi.org/10.1108/APJML-11-2015-0172

Rauyruen, P., \& Miller, K. E. (2007). Relationship quality as a predictor of B2B customer loyalty. Journal of Business Research, 60(1), 21-31. https://doi.org/10.1016/j.jbusres.2005.11.006

Russell-Bennet, R., McColl-Kennedy, J. R., \& Coote, L. V. (2007). Involvement, satisfaction and brand loyalty in a small business services setting. Journal of Business Research, 60 (12), 1253-1260. https://doi.org/10.1016/ .jbusres.2007.05.001

Seppanen, R., Blomqvist, K., \& Sundqvist, S. (2007). Measuring inter-organizational trust — A critical review of the empirical research in 1990-2003. Industrial Marketing Management, 36(2), 249-265. https://doi.org/10.1016/ j.indmarman.2005.09.003

Shi, W. H., Chen, J. J., \& Ma, J. M. (2011). A study of customer loyalty based on switching cost and brand attachment. The Journal of China Universities of Posts and Telecommunications, 18, 136-141. https://doi.org/10.1016/S10058885(10)60195-1

Skarmeas, D., Zeriti, A., \& Baltas, G. (2016). Relationship value: Drivers and outcomes in international marketing channels. J. Int. Mark., 24(1), 22-40. https://doi.org/10.1509/jim.15.0065

Stan, V. (2015). Antecedents of Customer Loyalty in the Retailing Sector: The Impact of Switching Costs. The Journal of Applied Business Research, 31(2), 371-382. https://doi.org/10.19030/jabr.v31i2.9121

Theron, E., Terblanche, N. S., \& Boshoff, C. (2008). The antecedents of relationship commitment in the management of relationships in business-to-business (B2B) financial services. Journal of Marketing Management, 24(9/10), 9971010. https://doi.org/10.1362/026725708X382019

Vaidyanathan, G., \& Devaraj, S. (2008). The role of quality in e-procurement performance: An empirical analysis. Journal of Operations Management, 26 (3), 407-425. https://doi.org/10.1016/j.jom.2007.08.004

Vaitone-Vilkaite, N., \& Papsiene, P., (2016). Influence of Customer Loyalty Program on Organizational Performance: a Case of Airline Industry. Inzinerine Ekonomika-Engineering Economics, 27(1), 109-116. http://dx.doi.org/10.57 55/j01.ee.27.1.10267

Vazquez-Carrasco, R., \& Foxall, G. R. (2006). Positive vs. negative switching barriers: the influence of service consumer's need for variety. Journal of Consumer Behavior, 5, 367-379. https://doi.org/10.1002/cb.187

Wirtz, J., Xiao, P., Chiang, J., \& Malhotra, N. (2014). Contrasting the drivers of switching intent and switching behaviour in contractual service settings. Journal of Retailing, 90(4), 463-480. https://doi.org/10.1016/j.jretai.2014.07.002

Woisetschlager, D. M., Lentz, P., \& Evanschitzky, H. (2012). How habits, social ties, and economic switching barriers affect customer loyalty in contractual service settings. Journal of Business Research, 64 (8), 800-808. https://doi.org/10.1016/j.jbusres.2010.10.007

Wu, L. Y., Chen, P. Y., \& Chen, K. Y. (2015). Why does loyalty-cooperation behavior vary over buyer-seller relationship? Journal of Business Research, 68(11), 2322-2329. https://doi.org/10.1016/j.jbusres.2015.04.001

Yang, Sh. (2015). Understanding B2B customer loyalty in the mobile telecommunication industry: a look at dedication and constraint. Journal of Business \& Industrial Marketing, 30(2), 117-128. https://doi.org/10.1108/JBIM-05-2013-0105

Young, L. (2006). Trust: looking forward and back. Journal of Business \& Industrial Marketing, 21(7), 439-445. https://doi.org/10.1108/08858620610708920

Zeithaml, V. A., Berry, L. L., \& Parasuraman, A. (1993). The nature and determinants of customers expectation of service. Journal of the Academy of Marketing Science, 21(1), 1-12. https://doi.org/10.1177/0092070393211001

The article has been reviewed.

Received in February, 2018; accepted in February, 2019. 